Geological Society, London, Special Publications

Facts and fancies: the Geological Society of London and the wider public, 1807-1837

Ralph O'Connor

Geological Society, London, Special Publications 2009; v. 317; p. 331-340 doi:10.1144/SP317.19

Email alerting service

Permission request

Subscribe click here to receive free email alerts when new articles cite this article

click here to seek permission to re-use all or part of this article

click here to subscribe to Geological Society, London, Special Publications or the Lyell Collection

Notes

Downloaded by University of Aberdeen on 24 August 2009 


\title{
Facts and fancies: the Geological Society of London and the wider public, 1807-1837
}

\author{
RALPH O'CONNOR \\ Department of History, University of Aberdeen, Crombie Annexe, Meston Walk, \\ Aberdeen AB24 3FX, UK (e-mail: ralph.j.oconnor@gmail.com)
}

\begin{abstract}
The leading lights of the Geological Society announced the birth of a newly scientific form of Earth science by claiming to dissociate geology from the grand theories, theological controversialism and flights of fancy that they felt had dominated eighteenth-century practice. For these gentlemen, geology was to comprise strict empirical induction. They cultivated a historical myth according to which their predecessors had been hopelessly romantic theory-mongers with overactive imaginations, while they themselves were sensible, sober men of science.

But if this was so, how did geology succeed in winning such an enormous middle- and upperclass public by the late 1830s? Public support required public interest, and public interest in this period was most easily stirred by the romantic, the speculative and the poetical. Older theories of the Earth remained popular for this very reason, as did biblically literalist reconstructions of Earth history. The challenge for the new school of geology was to dissociate Earth science from the content and methodology of such theories while retaining their accompanying sense of excitement, wonder and pleasure. This paper explores how members and allies of the Geological Society negotiated (or ignored) their own suspicions about the deceptive power of the 'imagination' when promoting geology as a science worth the public's attention.
\end{abstract}

One of the chief means by which the Geological Society's founders presented themselves as leading figures was to redefine 'geology' as a strictly empirical science, devoted to fact-gathering rather than speculation. This was not merely a bid to avoid the undignified cosmological polemics that they felt marred geological debate in Edinburgh. Speculation was a dangerous business in earlynineteenth-century London. The ruling classes were still anxious about the possibility of revolution breaking out in Britain; many of them blamed the recent French Revolution on French Enlightenment intellectuals, whose subversively secular speculations had supposedly encouraged the masses to rise up against Church and State. Geology was one of the new sciences that ended up being tarred with this brush (Porter 1978, pp. 435-436) because its best-known literary medium - the 'theory of the Earth' - was an extremely speculative genre, often dealing in grand narratives of Earth history and often ignoring (or being very creative with) the biblical text of Genesis 1. Geology, according to conservative commentators throughout the early nineteenth century, was a symptom of 'the malaria of French philosophy' (Brown 1838, p. 38).

How then to cure geology of French malaria? The Geological Society's official solution was to purge their science of any vestige of grand theory, theological controversy and, above all, an excess of imagination (Laudan 1977; Porter 1977 , pp. 204-208; compare Daston 2001). Writing theories of the Earth was indefinitely postponed; for now, geologists were to gather and arrange facts in line with the empirical philosophy advanced by Francis Bacon two centuries earlier. ${ }^{2}$ The first volumes of the Society's Transactions bore a Latin epigraph taken from Bacon's Novum Organum including the injunction 'non belle et probabiliter opinari, sed certo et ostensive scire' ('not to produce attractive and plausible conjectures, but certain and demonstrable knowledge'). ${ }^{3}$ The Society's spokesmen presented this Baconianism as fully in line with developments in other sciences, all of which were beginning 'to assume a character of strict experiment or observation, at the expense of all hypothesis, and even of moderate theoretical speculation' ([Fitton] $1817 a$, p. 175). If 'systems'

\footnotetext{
${ }^{1}$ On the effects of the conservative backlash in the years following the French Revolution, see Morrell (1971) and Brooke \& Cantor (1998, pp. 195-200).

${ }^{2}$ A similar redefinition of geology was being undertaken by savants in Napoleonic France, less narrowly empiricist than the English equivalent but employing precisely the same strategy of disparaging more speculative approaches as romantic nonsense (Rudwick 2005, pp. 456-463).

${ }^{3}$ Title page. Transactions of the Geological Society, 2, i. (1814).
} 
of any kind were to be avoided, philosophical ignorance could even be trumpeted as a gentlemanly virtue. William Fitton noted without any irony that:

the members of the Geological Society have derived great benefit from their want of systematical instruction [....] They were neither Vulcanists nor Neptunists, nor Wernerians nor Huttonians, but plain men, who felt the importance of a subject about which they knew very little in detail.

([Fitton] $1817 b$, p. 70)

By remaining ostentatiously unbiased by any theoretical allegiance, this new breed of philosophers could reinforce their status as disinterested and 'sober-minded' gentlemen in the conservative political climate of the early nineteenth century ([Fitton] 1817a, p. 177).

If the geologists saw themselves as 'plain men', it did not necessarily follow that all plain men could hope to become geologists. In their pamphlet, Geological Inquiries, first issued in 1808 and reprinted in various forms well into the 1810s, George Greenough and his colleagues urged the public to take their place in the hierarchy of knowledge production by sending specimens and observations to the Geological Society, envisaged as a 'repository for any facts that may be communicated to them'. Only the gentlemanly philosopher, with an independent income to guarantee his 'total devotion of time' to his science, could hope some day to 'reduce Geology to a system', but such a system was perceived as (at best) a distant future promise rather than something attainable or even desirable at the present time (Anon. 1817, pp. 421-422). Fitton announced to readers of the Edinburgh Review in 1817 that:

matter-of-fact methods have lately been gaining ground in Geology [...] hypotheses are now scarcely listened to; and even the well-organized theories which, a short time since, created so much controversy, receive in this day little attention or comment.

([Fitton] $1817 a$, p. 177)

Fitton was certainly overstating the case: theories of the Earth continued to be read and enjoyed by the intelligentsia. But his statement reveals the kind of philosophical practice that the Geological Society wished to promote among the wider public in the 1800 s and 1810 s as part of its programme to redefine the scope and nature of geology.

As with many disciplines emerging in the early nineteenth century, geology's self-styled elite forged a historical myth in which they represented enlightenment liberated from a benighted era of fable and superstition, or as a science that had outgrown its 'infancy of speculation and conjecture' ([Fitton] 1817a, p. 176; see Porter 1977, p. 148). For the Geological Society, rebranding 'geology' usually meant being rude about their predecessors on whose shoulders they were standing. Men like Thomas Burnet, the Comte de Buffon and even Jean André Deluc were publicly castigated for having let their imaginations run away with them. Members of the Society used widely circulating periodicals and public lectures to ensure that the British intelligentsia got the message. In his 1805 geology lectures at the Royal Institution, for instance, Humphry Davy called Burnet's work 'highly interesting and entertaining' as a 'poetical romance', but from a 'philosophical' viewpoint 'wholly unworthy of attention' (Siegfried \& Dott 1980, p. 43).

Other members and associates of the Geological Society wrote admiring reviews of early issues of the Society's Transactions in leading literary periodicals such as the Edinburgh Review. Such reviews typically began by alluding to the dark ages of unbridled imagination against which the new Baconians stood. John Playfair, who since the death of James Hutton had reinvented himself as a thorough empiricist (Porter 1977, p. 207), opened his review of the first volume in 1811 by looking back to:

the time when the vague and cursory information that every man might glean from the objects that were perpetually before him, when combined and magnified by a powerful imagination, was sufficient for all the purposes of geological speculation. According to this view of the matter, a man [...] stood no more need of the assistance of others, than if he had been at work in the regions of Poetry or Romance.

([Playfair] 1811-1812, p. 207)

The result had been a rash of "visionary and fantastic theories', or what Fitton (when introducing his review of the third volume in 1817) called 'easy and tempting speculations which, till of late, it has been the fashion to dignify with the name of Geology' ([Playfair] 1811-1812, p. 207; [Fitton] $1817 b$, p. 74; compare [Fitton] 1823-1824, p. 196). The contrast between these sober Baconians and their romantic predecessors was sometimes stretched to the point of caricature, as when Playfair referred to early geology as 'a species of mental derangement, in which the patient raved continually of comets, deluges, volcanos and earthquakes' ([Playfair] 1811-1812, p. 207). All this was set in sharp relief by a sensible chap like Greenough, whom one could rely on to gather facts or take one out for expensive dinners. As John Ayrton Paris put it, 'The fabulous and romantic age of geology may be said to have passed away' (Paris 1818, p. 168).

In the $1800 \mathrm{~s}$ and $1810 \mathrm{~s}$, then, various members of the Geological Society of London were engaged in disseminating a flattering image of themselves as scientific reformers and architects of a collaborative research programme, set against a backdrop of bad practice depicted in terms of the romantic 
and imaginative excesses of solitary would-be geniuses. This picture has since become embedded in popular accounts of the 'heroic age' of geology. It needs to be taken with more than a pinch of salt, on several levels. First, it completely misrepresents the aims, achievements and practices of previous investigators into the structure and history of the Earth; this point is too obvious to need defending here (see Porter 1977; Rudwick 2005).

More importantly, its characteristic trope of setting 'truth' against 'imagination' is a blunt polemical instrument and one of the oldest tricks in the rhetorical armoury of Western literature for discrediting an opponent (see Heringman 2004, pp. 269-271). It should not be taken as evidence that science and the imagination, or science and speculation, were necessarily seen as mutually exclusive in all circumstances by the person wielding this rhetorical instrument. For instance, in a book published in 1831 but drafted long before, John MacCulloch (1773-1835) cast aspersions on the diluvial theory by alluding to 'that love of the marvellous which so often loses sight of science, and of truth also'; but he made this remark in a book that defended the practice of speculation and was itself subtitled $A$ Theory of the Earth (MacCulloch 1831, vol. I, p. 448). He was also renowned for the poetic quality of his geological writings on the Hebrides, which were often excerpted by later popularizers wishing to exploit their readers' love of the marvellous (e.g. Mantell 1838, p. 644). For MacCulloch, the romantic imagination had its place in scientific writing as long as it was not felt to intrude on the sacred ground of scientific reasoning. For the more severely empirical Greenough, romantic effusions about nature were kept at bay in his published writings but indulged to the full in his private diaries (Wyatt 1995, pp. 172-174).

Furthermore, although empiricism continued to play a defining role in its public image, in practice the Geological Society did not long hold to the extreme empiricism favoured by Greenough. In the 1810 s the Society's more recent recruits, such as Thomas Webster, William Buckland and the Conybeare brothers, began serious attempts to correlate strata across large tracts of Britain and (later) Europe (Rupke 1983, pp. 118-123). Theory and generalization were central to this enterprise: hard-line empiricists such as Greenough and John Kidd rejected the idea of a standard stratigraphy for this very reason (see, for example, Greenough 1819), but by the late 1810 s research of this kind was taking up a sizeable proportion of the Society's Transactions, along with William Smith's method of using characteristic fossils to identify strata. For geologists like Buckland (as for his Continental colleagues) this opened the door once again to the possibility of reconstructing a history of the Earth and its inhabitants, a still more speculative and imaginative pursuit.

In various ways, then, the Geological Society's embargo on speculation and imagination operated in much more limited ways than might be thought from the prominence of this rhetoric in the Society's public statements. Even here the Society's position was not unambiguous. For every assertion of sober empiricism in review articles, popular treatises or public lectures, one may find at least one counterbalancing assertion of geology's significance in terms of its appeal to the speculative imagination, and such assertions often used explicitly 'visionary' or romantic language. The reason for this was simple. It was all very well for Greenough and his colleagues to advise their projected regional network of investigators to act as docile fact-gatherers, but in order to maintain this network (and support from the wider public) it was necessary from the very beginning to ensure that geology retained its traditional appeal as a romantic, sublime, imaginatively inspiring endeavour. Even Geological Inquiries conceded this point, referring to geology as 'a sublime and difficult science', a juxtaposition that nevertheless implies that only those with leisure to comprehend the many difficulties of the science would be able to attain its 'sublime' heights (Anon. 1817, p. 421).

The old theories of the Earth had won much of their readership and cultural prestige not because of their economic utility, but because their romantic visions of former worlds and apocalyptic cataclysms had caught their readers' imaginations, somewhat along the lines of the huge historical landscapes being painted in the late eighteenth and early nineteenth centuries by such artists as Philip James de Loutherbourg, J. M. W. Turner and John Martin (Paley 1986; Boime 1990, 2004). Burnet's Restoration-era Sacred Theory of the Earth was still admired in the Regency period as a great work of literature (Jackson 1985, p. 318), and deservedly so. If the kind of geology being promoted by the Geological Society was to gain the cultural prestige it needed, it had to provide this kind of interest for a wider audience. For those who engaged in popularization (by which word I mean simply 'making something more widely known'), this would mean cultivating imaginative excess and encouraging speculation among their public, in the teeth of the Society's official party line. In what remains of this paper I shall outline some of the ways in which this was done in the Society's first three decades. ${ }^{4}$

\footnotetext{
${ }^{4}$ For a detailed account of how geology was popularized in early nineteenth-century Britain, see O’Connor (2007b).
} 


\section{Popularization}

Today we often use the word 'popularization' to refer to information handed out relatively cheaply to ordinary people, but very few readers of geology books or audiences at geology lectures were ordinary people: they were the wealthiest and most prestigious sector of society. The disparity in incomes across the social spectrum was far greater in the early nineteenth century than it is today. The top slice of church livings earned their incumbents over $£ 1000$ per annum. ${ }^{5}$ Many curates earned as little as $£ 50$ per annum; clerks, tradesmen and servants would be lucky to earn half that. To make this point more concretely, Table 1 gives some examples of the real-life cost of a few geological essentials for a typical lower-middle-class earner, a lawyer's clerk in London in the 1830s.

It comes as a shock to realize that the classic fossil treatise of the Napoleonic years, James Parkinson's Organic Remains of a Former World (1804-1811), would have cost our lawyer's clerk almost a third of his annual earnings. Books before the 1840s were prohibitively expensive, cheap periodicals were in their infancy and, in any case, most of the British (or at least English) population were illiterate or only semi-literate. ${ }^{6}$ As for museums, it may be true that before the 1830s many cabinet collections charged no entry fee, such as Gideon Mantell's museum in Lewes. But most museums were private-membership institutions: you had to know the right people. You could collect fossils for free (depending on the locality); but keeping up to date with the latest developments in geology was a different proposition. Geology in early nineteenth-century Britain was an exclusive science, unless you happened to be practising it for a living like William Smith.

Let us now examine how geologists and their allies sought to awaken these audiences' excitement, wonder and pleasure at the new science. We glance first at two of the Geological Society's founders, Humphry Davy and James Parkinson.
Both men brought poetry back into the science by promoting it well outside a Geological Society context. By 1807 Davy was one of the most celebrated and flamboyant lecturers in London (Golinski 1992; Knight 1992), famous (if contemporary caricatures are to be taken literally) for inducing fits of chortling and farting with his newly discovered gas, nitrous oxide. Contemporary journalists found this hilarious. Davy was the star performer at the prestigious Royal Institution, where his research was sponsored by aristocrats who, besides agricultural utility, wanted some fun for their money. Between 1805 and 1811 Davy also lectured on geology, promoting it as an extension of the Grand Tour:

The imagery of a mountain country, which is the very theatre of the science, is in almost all cases highly impressive and delightful, but a new and a higher species of enjoyment arises in the mind when the arrangements in it [...] are considered.

(Siegfried \& Dott 1980, p. 13)

Davy's procedure is typical of scientific popularizers in his day, as in our own: he latches onto something his audience already takes pleasure in (going on expensive holidays) and channels this pleasure in a new direction. His Elements of Agricultural Chemistry (1813) contains a striking visual parallel to this process, incorporating a picturesque engraving of mountains by Thomas Webster, designed to give both pleasure and mineralogical information (Fig. 1). As he put it in his lectures:

Every mountain chain offers striking monuments of the
great alterations that the globe has undergone. The
most sublime speculations are awakened, the present
is disregarded, past ages crowd upon the fancy, and
the mind is lost in admiration of the designs of that
great power who has established order in which at
first view appears as confusion. (Siegfried \& Dott 1980, p. 13)

This does not sound much like the hard-nosed empirical programme sketched out in Geological Inquiries, but Davy knew that to win over his audience he had to capture their imaginations.

\footnotetext{
${ }^{5}$ To gain a crude sense of what this figure might signify in present-day terms, one might compare today's median average British full-time annual salary (c. $£ 21840$ in 2006) with a typical 'comfortably middle-class’ British income in the 1830s, 48 shillings per week (see Topham 1992, p. 400 n. 19). This would deliver a ratio of 1:175 for pounds sterling, making the church living cited worth $£ 175000$ today. However, this ratio would represent only a 'comfortably middle-class' perspective and cannot be applied across the board. Rudwick (1985, p. 461) has suggested 1:40 from a more genteel perspective, while Taylor \& Torrens (1986, pp. 145-146) have suggested 1:200 from a farm labourer's perspective. Even in this limited domain, such ratios are useful only as very general pointers, because of serious discrepancies across time in the cost of living, taxation policy and other important variables (on the costs of living in this period see Burnett 1969).

${ }^{6} \mathrm{~T}$. W. Heyck, drawing on a range of statistical accounts relating to England and Wales, suggests 'that in the early Victorian years more than a third of the population was illiterate, and that perhaps another third to a half was only semi-literate' (i.e. unable to read connected prose) (Heyck 1982, p. 26). This would leave between one-sixth and one-third of the population fully literate. On working-class literacy see Vincent (1989).
} 
Table 1. The cost of geology. Costs of some items for a London clerk earning 10s a week

\begin{tabular}{|c|c|c|}
\hline Item & Cost & Cost in real terms \\
\hline $\begin{array}{l}\text { First year's membership of the Geological } \\
\text { Society of London in the 1830s (admission fee } \\
\text { plus annual subscription) }\end{array}$ & 9 guineas $(£ 99 s)$ & $4 \frac{1}{2}$ months' wages \\
\hline Parkinson's Organic Remains (1804-1811) & 8 guineas & 16 weeks' wages \\
\hline Buckland's Geology and Mineralogy (1836) & $£ 115 s$ & 3 weeks' 2 days' wages \\
\hline $\begin{array}{l}\text { 'Cheap' edition of Lyell's Principles of Geology } \\
\text { (1834) }\end{array}$ & $24 s$ & 2 weeks' 2 days' wages \\
\hline $\begin{array}{l}\text { Annual subscription to Mudie's circulating } \\
\text { (i.e. lending) library }\end{array}$ & 1 guinea & 2 weeks' wages \\
\hline $\begin{array}{l}\text { Entry fee to many commercial museums and } \\
\text { exhibitions }\end{array}$ & $1 s$ & 0.6 day's wages \\
\hline $\begin{array}{l}\text { Samuel Clark's educational book The Little } \\
\text { Geologist (c. 1840) }\end{array}$ & $1 s$ & 0.6 day's wages \\
\hline $\begin{array}{l}\text { Quartern loaf of bread (c. } 2 \mathrm{~kg} \text {, i.e. four times as } \\
\text { much bread as today's supermarket loaf) }\end{array}$ & $10 d$ & $\frac{1}{2}$ a day's wages \\
\hline
\end{tabular}

A similar strategy was used by Parkinson, whose three-volume magnum opus Organic Remains was written in epistolary form for an audience of genteel collectors (Thackray 1976). Collectors at this time often treated fossils as curious and attractive objects, and the fictional protagonist of Parkinson's book has just realized how little he knows about such objects:

How mortifying will it be to have objects presented daily to my view, whose form alone renders them highly interesting; and whose history is probably fraught with entertainment; and to find myself totally ignorant of their origin.

(Parkinson 1804-1811, vol. I, p. 5)

The protagonist writes in this vein to a learned friend, who promises to send him 'a regular, and systematic history' of organic remains. The rest of the trilogy is taken up with the friend's letters, lavishly illustrated with coloured engravings. Entertainment is duly promised in spectacular descriptions of monsters:

you will behold the bones of an animal, of which the magnitude is so great; as to warrant the conviction, that the bulk of this dreadful, unknown animal, exceeded three times that of the lion; and to authorise the belief, that animals have existed, which have possessed, with all the dreadful propensities of that animal, its power of destroying, in a three-fold degree. In a word, you will be repeatedly astonished.

(Parkinson 1804-1811, vol. I, p. 11)

Organic Remains, published between 1804 and 1811 , had only limited relevance to the mainly mineralogical focus of the Geological Society around this time, but it was important in tapping into a genteel interest in fossils as aesthetically pleasing curiosities, and moulding that interest into something more philosophically focused. Like Davy, then, Parkinson presented geology as something that could satisfy, and indeed outdo, an existing enthusiasm among the upper classes.

The importance of the romantic, speculative dimension to the popularization of geology becomes still clearer when we look at what happened when popularizers ignored it in favour of a rigid empiricism. In MacCulloch's Geological Classification of Rocks, intended to impart 'the Elements of Practical Geology' to his public (MacCulloch 1821, title page), the author confined himself to describing and classifying rock types without drawing any causal inferences from them, let alone speculating on Earth history. The Eclectic Review was not impressed. Geology, its reviewer stated, was by its very nature 'romantic' and speculative, and MacCulloch's allusion to geology in his title seemed to promise more than mere mineralogy:

The mere study of rocks, as it is here brought before us, is dry and revolting, apart from the inferences and discussions which belong to Geology. [...] there are few persons, we imagine, who would sit down with pleasure to such a catalogue as is here given of rocks, when it is made the ultimatum. [...] What are we to do with the elementary knowledge derived from Dr. Macculloch? Does he intend, that we should commit to memory his descriptions, and his divisions, and subdivisions, and then rest in quiet suspense [...]? This is certainly too much for the patience of ordinary inquirers.

(Anon. 1821, p. 432)

It is worth pointing out that this reviewer had no problem with the Geological Society's redefinition of geology against their overly imaginative 


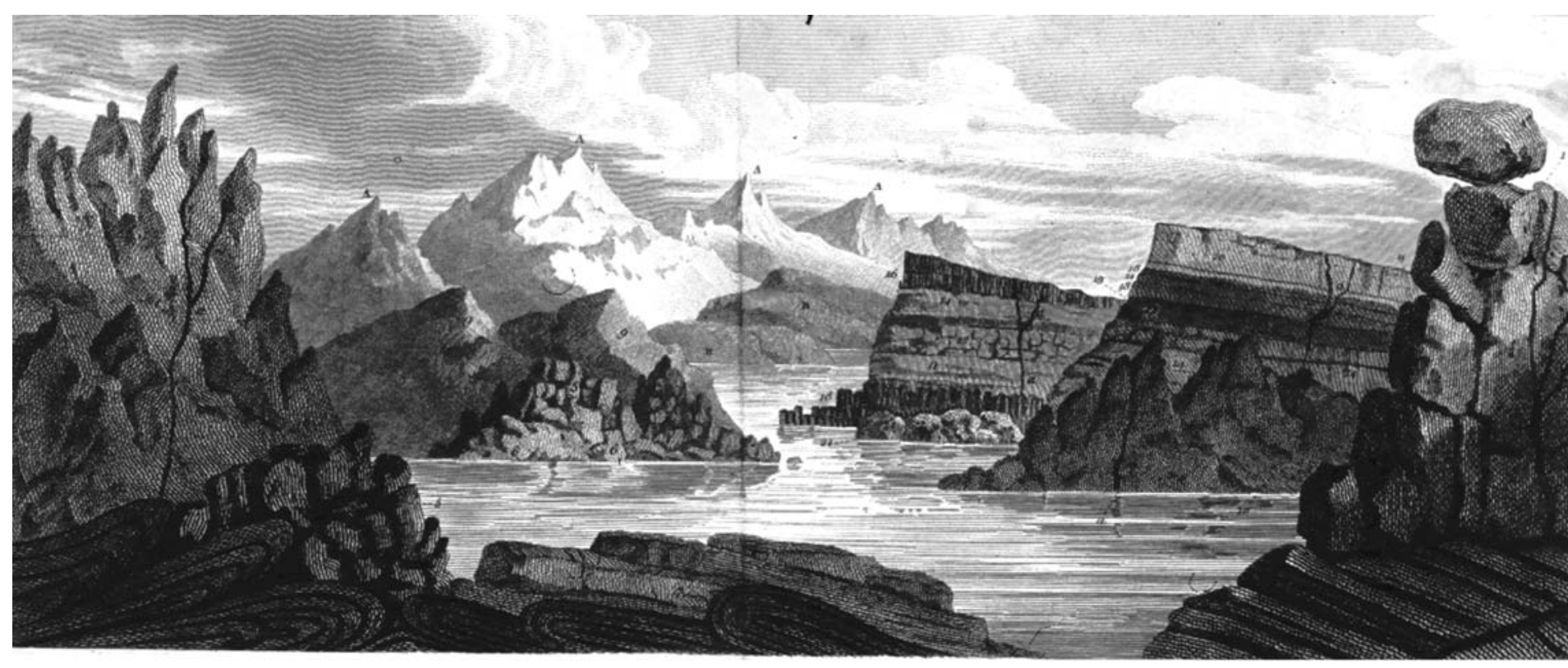

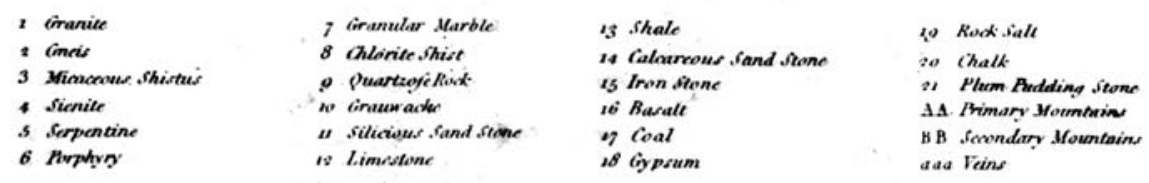

Fig. 1. Keyed diagram of rock types, painted by Thomas Webster and engraved by F. C. Bruce for Davy's (1813) Elements of Agricultural Chemistry. This diagram represents a striking blend of picturesque and scientific visual conventions (Davy 1813, fig. 16). Reproduced by kind permission of the Syndics of Cambridge University Library. 
predecessors, as long as imagination were not allowed to gain the upper hand entirely. Geology was still, the reviewer insisted, a thoroughly romantic science:

In calling Geology romantic, we refer not to the tissues of wild conjecture and descriptions of unreal events, which Burnet and Buffon dignified with the name of "Theories of the Earth." Such were not science, but an exercise of fancy, an embodying of waking dreams into a beautiful, perhaps, but an improbable system of world-making. We say that Geology is a romantic science independently of its fabulous historians.

(Anon. 1821, p. 431)

Geology was romantic because it was 'a new and interesting branch of Antiquities', leading to speculations about such topics as 'the original chaos' and 'the effects of the Deluge'. In the mind of this and many other readers, popularizers of geology (at least from the late 1810s and later) who omitted such grand historical speculations altogether from their work were not doing their job properly. MacCulloch's later defences of geological theorizing suggest that he had taken the point: he introduced his own provisional 'Sketch towards a Theory of the Earth' by observing that 'To omit such a view' in a work intended for 'the mere student' would be 'a dereliction of duty, as it would be to disappoint reasonable expectation' (MacCulloch 1831, vol. II, p. 410).

This was certainly clear enough to Buckland, who by the early 1820 s was expounding the grand historical aspects of geology at Oxford University, the prime training ground for England's elite clergymen and an important base for generating wider support for the science (Rupke 1983). Mixing Genesis with geology also went against the Geological Society's party line, but Britain's future intelligentsia needed to be taught how and why geology represented a valuable support for Scripture, rather than a threat. More than this, Buckland brought the science to life for his students. With the help of visual aids, private jokes, outdoor field trips and his own impersonations of extinct animals, he helped them to imagine the former worlds he was talking about, speculating in the most spectacular way imaginable and making full use of the comic potential of fossil hyena droppings along the way (O'Connor 2007b, pp. 71-116). It was around Buckland that the practice of composing occasional verses on geology really took on a life of its own, and these verses - circulated privately among fellow dons and geologists - served as a useful testing ground for imaginative techniques that would soon be launched before a wider public, with their tongue-in-cheek tales and songs about heroic geologists and the wonders of the distant past they explored.

By the mid-1820s mammoths and hyenas were old news, and a new range of fossil monsters lurched into the limelight: the saurians. ${ }^{7}$ These gave rise to some of the most entertaining papers among the normally rather dry Transactions of the Geological Society: Buckland's 1829 paper on pterodactyles even contained a lurid quotation from Paradise Lost (Buckland 1835, p. 219). But the fossil saurians also offered a golden opportunity to take up where Parkinson had left off. This opportunity was seized by the Sussex surgeon Gideon Mantell, a key figure in the identification of the great lizards later to be termed 'dinosaurs'. Like Parkinson, Mantell targeted his first two books $(1822,1827)$ at wealthy landowners with an interest in local history - and the local history of Sussex now stretched back into the pre-human period. Also like Parkinson, Mantell stressed the enormous size of these extinct creatures:

If we attempt to pourtray the animals of this ancient country, our description will possess more of the character of a romance, than of a legitimate deduction from established facts. [...] The gigantic Megalosaurus, and yet more gigantic Iguanodon, to whom the groves of palms and arborescent ferns would be mere beds of reeds, must have been of such a prodigious magnitude, that the existing animal creation presents us with no fit objects of comparison.

(Mantell 1827, p. 83)

Here the official rhetoric of the Geological Society, disparaging the exercise of fancy and imagination as unhealthy 'romance', is apparently turned on its head. Mantell not only admits that an accurate geological description is bound to sound like a romance, but he uses this as a positive selling-point for the science. His stance is not far from that of a circus ringmaster, a strategy that enabled ambitious geologists like Mantell to enhance their own prestige and authority in front of an awestruck audience.

That same year (1826), the young Charles Lyell performed a similar feat for the readers of the Quarterly Review. The Quarterly was the most prestigious of the more conservative review periodicals: this was where the Tory intelligentsia came for current opinion on key cultural issues. Like Playfair and Fitton in the Whiggish Edinburgh Review, Lyell used the Quarterly as a platform to canvass support for the Geological Society by trumpeting its recent

\footnotetext{
${ }^{7}$ Ichthyosaurs and pterodactyles had been known to fossilists and geologists long before Buckland's hyena den research, but they were not widely publicized in Britain until the early $1820 \mathrm{~s}$ in the wake of discoveries of the iguanodon, megalosaurus and plesiosaurs.
} 
discoveries. But whereas Playfair and Fitton had used the concepts of 'romance' and 'poetry' as sticks with which to beat eighteenth-century theorists, contrasting them with the sober and narrower practices of modern geologists, Lyell used these same concepts to play up the spectacular appeal and visionary possibilities of present-day geology. In a long review of the Society's 1824 Transactions, Lyell presented palaeontology as a realization of the fictitious monsters of mediaeval romance:

We cannot wonder that geologists have been suspected of a love for the marvellous. [...] The Pterodactyls [...] or flying lizards, described by Cuvier, recal still more forcibly to our recollection the winged dragons of fabulous legends. [...] the size of some of them, their long jaws armed with sharp teeth, and the hooked nails of their claws, would render them truly terrific were they to revisit Christendom, now no longer under the shield of the Seven Champions.

([Lyell] 1826, pp. 523-524).

The 'love of the marvellous' is here invited back in to the discourse of geology as a selling point for outsiders, albeit at the level of metaphor and simile rather than causal explanation. Lyell even uses the word 'terrific', a staple adjective of contemporary Gothic novels. His readers liked reading romances, so he advertised geology to them by presenting it as a romance. This analogy became a mainstay of polite geological popularization in the Victorian period, even when print became cheap enough for the working classes. Romance was a capacious literary form, embracing everything between Edward Bulwer-Lytton's silver-fork novels and the penny dreadfuls, and appealing right across the class spectrum; accordingly, romance was an ideal touchstone for popularizers.

The idea of geology as a romance was also a mainstay of biblically literalist geological popularization, which enjoyed a considerable vogue in the 1820 s - much to the annoyance of the Geological Society, whose members felt that this threatened 'to take us back again to the darker ages of geology' ([Fitton] 1823-1824, p. 206). Part of the problem was that the literalists often pre-empted the self-styled geological elite in bringing the new science before a wider public. One popularizer of literalist geology, James Rennie, wrote an attractive and successful series of introductory Conversations on Geology between a mother and her two children, in which the mother states:

I [. . . call Geology romantic, because it not only leads us to travel among the wildest scenery of nature, but carries the imagination back to the birth and infancy of our little planet, and follows the history of deluges and hurricanes and earthquakes.

([Rennie] 1828 , p. 8)
From the 1820s onwards, old-Earth and youngEarth geologies were promoted in competition with each other (O'Connor 2007a). Both sides often had harsh things to say about their competitors, but they were also quick to latch onto and cannibalize each other's innovations in spectacular rhetoric, attractive analogies, pictorial techniques, publication formats and display media. Geology rose to celebrity in the 1830 s on the back of a rhetorical and iconographic 'arms race' in which new audiences were targeted and new genres colonized. Buckland, for instance, recycled his Oxford lecturing techniques before the mixed audiences of the British Association for the Advancement of Science, leading field trips on horseback and delighting onlookers with his saurian impersonations (Morrell \& Thackray 1981, pp. 158-159). Mantell, meanwhile, commissioned George Scharf to paint a huge pictorial representation of his iguanodon description to hang in his museum in Brighton, bringing the infant genre of 'scenes from deep time' (Rudwick 1992) out from the realm of privately circulated caricature into the public spotlight.

Lyell's own public-relations efforts in the 1830s were so successful that they won him a lasting place in the geological pantheon. The historical importance of his Principles of Geology (1830-1833) lies less in any scientific breakthrough he achieved than in the masterly way in which he synthesized and dramatized existing knowledge before a wider public, first among the upper classes, then (with the cheaper edition of 1834) among the wealthier members of the middle classes. Laced with attractive poetry quotations and framed as a reflective philosophical treatise rather than a simple textbook, the Principles also helped to accelerate the ongoing shift in Geological Society practice away from hard-line empiricism towards a climate in which theoretical speculation once again had a central role to play. Not everyone approved of Lyell's imperialistic approach to other people's work, but his choice of genre enabled him to go public on many issues which the Geological Society had largely kept quiet about before, such as the immensity of past time. By bringing the depth of geological time fully before his readers' imaginations, Lyell's literary gifts played a major role in cementing the public status of geology as a discipline in its own right (Secord 1997, p. xxiii).

But the most distinctive feature of Victorian geological popularization was something Lyell strenuously denied, the evidence for progression in Earth history. This evidence enabled other geological writers to engage the literalists head-on, recasting and amplifying Genesis 1 as a stately pageant from primitive plants to humans, a cosmic 
drama spanning millions of years to match the vast tracts of space revealed by astronomy. Buckland's 1836 Bridgewater Treatise, Geology and Mineralogy, was one of the earliest and best-known embodiments of this new creation-myth, which spawned countless imitations, successors and competitors. These grand narratives, infused with a sense of divine providence and the inevitable progress of civilization, inhabited numerous different genres and drew on a bewildering range of literary and mythological reference-points in order to harness the dramatic appeal of the old 'theories of the Earth' for the benefit of modern science. In the hands of Mantell and Hugh Miller, this kind of storytelling entered the realms of high art (O'Connor 2007b, pp. 357-432). It proved extremely durable, forming the bedrock of the 'evolutionary epic' as expounded by later popularizers such as Robert Chambers, Thomas Huxley and Richard Dawkins (Secord 2000, pp. 77-110; Lightman 2007, pp. 219-294; Dawkins 2004).

\section{The return to speculation}

Thirty years after its foundation, then, the Geological Society had come full circle. Theoretical speculation was back at the heart of its practice; the Society's apparent equation of poetry with falsehood had been flaunted by countless quotations from poems both old and new, not only in popular books but even in its Transactions; 'love of the marvellous' was no longer a byword for delusion; and the providential momentum of Protestant biblical scholarship was put to new use in telling the story of life before man. Nor was the imagination invited back in at a merely decorative level. Geology's propensity for grandiose cosmic speculation and the wild imaginings of romance, while simultaneously giving these visions the dignity of 'fact', pushed it to the top of the hierarchy of the sciences in Victorian Britain. Its capacity for reconstructing former worlds in all their glory, surely one of the most speculative endeavours in any branch of physical science, made it an important conceptual reference point by which other disciplines claimed 'scientific' status (such as anthropology, psychology and history). Credit for its prestige deserves to go to those who reconnected it with its roots. Despite John Ayrton Paris's confident claim (Paris 1818, p. 168), the 'romantic age of geology' was not dead and buried in 1818. It had only just begun.

I am grateful to Simon Knell and Noah Heringman for their detailed and helpful comments on this paper. Any remaining errors and overstatements for dramatic effect are mine alone.

\section{References}

ANON. 1817. Geological Inquiries, proposed by the Geological Society. Philosophical Magazine, 49, 421-429.

ANON. 1821. Macculloch on Rocks. Eclectic Review, 2nd series, 15, 430-441.

Boime, A. 1990. Art in an Age of Bonapartism 18001815. University of Chicago, Chicago, IL.

BoIme, A. 2004. Art in an Age of Counterrevolution 1815-1848. University of Chicago, Chicago, IL.

Brooke, J. \& CANTOR, G. 1998. Reconstructing Nature: The Engagement of Science and Religion. Clark, Edinburgh.

Brown, J. M. 1838. Reflections on Geology. James Nisbet, London.

BUCKLAND, W. 1835. On the discovery of a new species of Pterodactyle in the Lias at Lyme Regis [read 1829]. Transactions of the Geological Society of London, 2nd series, 3(1), 217-222.

BuCKLAND, W. 1836. Geology and Mineralogy Considered with Reference to Natural Theology (2 vols). William Pickering, London.

Burnett, J. 1969. A History of the Cost of Living. Penguin, London.

DASTON, L. 2001. Fear and loathing of the imagination in science. In: Graubard, S. R., Mendelsohn, E., Wilson, E. O. \& Galison, P. (eds) Science in Culture. Transaction, New Brunswick, NJ, 73-95.

DAvy, H. 1813. Elements of Agricultural Chemistry. Longman, London.

Dawkins, R. 2004. The Ancestor's Tale: A Pilgrimage to the Dawn of Life. Weidenfield \& Nicolson, London.

[FitTon, W. H.] 1817a. Transactions of the Geological Society. Vol II. Edinburgh Review, 28, 174-192.

[FITTON, W. H.] 1817b. Transactions of the Geological Society, Vol. III. Edinburgh Review, 29, 70-94.

[FitTon, W. H.] 1823-1824. Geology of the Deluge. Edinburgh Review, 39, 196-234.

Golinski, J. 1992. Science as Public Culture: Chemistry and Enlightenment in Britain, 1760-1820. Cambridge University Press, Cambridge.

Greenough, G. B. 1819. A Critical Examination of the First Principles of Geology; in a Series of Essays. Longman, London.

Heringman, N. 2004. Romantic Rocks, Aesthetic Geology. Cornell University, Ithaca, NY.

HeycK, T. W. 1982. The Transformation of Intellectual Life in Victorian England. Croom Helm, London.

JACKSON, H. J. (ed.). 1985. The Oxford Authors: Samuel Taylor Coleridge. Oxford University Press, Oxford.

KNIGHT, D. M. 1992. Humphry Davy: Science and Power. Blackwell, Oxford.

LAUDAN, R. 1977. Ideas and organizations in British Geology: A case study in institutional history. Isis, 68, 527-538.

Lightman, B. 2007. Victorian Popularizers of Science: Designing Nature for New Audiences. University of Chicago, Chicago, IL.

[LyELL, C.] 1826. Transactions of the Geological Society of London. Quarterly Review, 34, 507-540.

Lyell, C. 1830-1833. Principles of Geology, Being an Attempt to Explain the Former Changes of the 
Earth's Surface, by Reference to Causes Now in Operation (3 vols). John Murray, London.

MacCulloch, J. 1821. A Geological Classification of Rocks, with Descriptive Synopses of the Species and Varieties, Comprising the Elements of Practical Geology. Longman, London.

MacCulloch, J. 1831. A System of Geology, with a Theory of the Earth, and an Explanation of Its Connexion with the Sacred Records (2 vols). Longman, London.

Mantell, G. A. 1822. The Fossils of the South Downs; or Illustrations of the Geology of Sussex. Lupton Relfe, London.

Mantell, G. A. 1827 [published 1826]. Illustrations of the Geology of Sussex: Containing a General View of the Geological Relations of the South-Eastern Part of England. Lupton Relfe, London.

Mantell, G. A. 1838. The Wonders of Geology. Relfe and Fletcher, London.

Morrell, J. 1971. Professors Robison and Playfair, and the Theophobia Gallica: Natural philosophy, religion and politics in Edinburgh, 1789-1815. Notes and Records of the Royal Society of London, 26, 43-63.

Morrell, J. \& ThaCKRAY, A. 1981. Gentlemen of Science: Early Years of the British Association for the Advancement of Science. Clarendon, Oxford.

O'CONNOR, R. J. 2007a. Young-Earth creationists in nineteenth-century Britain? Towards a reassessment of 'scriptural geology'. History of Science, 45, $357-403$.

O'Connor, R. J. 2007b. The Earth on Show: Fossils and the Poetics of Popular Science, 1802-1856. University of Chicago, Chicago, IL.

Paley, M. D. 1986. The Apocalyptic Sublime. Yale University, New Haven, CT.

PARIS, J. A. 1818. Observations on the geological structure of Cornwall. Transactions of the Royal Geological Society of Cornwall, 1, 168-200.

PARKINSON, J. 1804-1811. Organic Remains of a Former World (3 vols). John Murray, London.

[Playfair, J.] 1811-1812. Transactions of the Geological Society. Edinburgh Review, 19, 207-229.

PORTER, R. 1977. The Making of Geology: Earth Science in Britain 1660-1815. Cambridge University Press, Cambridge.
PORTER, R. 1978. Philosophy and politics of a Geologist: G. H. Toulmin (1754-1817). Journal of the History of Ideas, 39, 435-450.

[RENNIE, J.] 1828. Conversations on Geology. Samuel Maunder, London.

Rudwick, M. J. S. 1985. The Great Devonian Controversy: The Shaping of Scientific Knowledge among Gentlemanly Specialists. University of Chicago, Chicago, IL.

RUDWICK, M. J. S. 1992. Scenes from Deep Time: Early Pictorial Representations of the Prehistoric World. University of Chicago, Chicago, IL.

RUDWICK, M. J. S. 2005. Bursting the Limits of Time: The Reconstruction of Geohistory in the Age of Revolution. University of Chicago, Chicago, IL.

Rupke, N. A. 1983. The Great Chain of History: William Buckland and the English School of Geology (18141849). Clarendon, Oxford.

SECORD, J. A. 1997. 'Introduction'. In: LyelL, C. Principles of Geology. (J. A. SECORD (ed.)). Penguin, London, ix-xliii. (Elibron Classics facsimile reprint of the 1837 edition by John Murray, London.)

SECORD, J. A. 2000. Victorian Sensation: The Extraordinary Publication, Reception, and Secret Authorship of Vestiges of the Natural History of Creation. University of Chicago, Chicago, IL.

SiEgFried, R. \& DOTT, R. H. JR. (eds). 1980. Humphry Davy on Geology: The 1805 Lectures for the General Audience. University of Wisconsin, Madison, WI.

TAYLOR, M. A. \& TORRENS, H. S. 1986. Saleswoman to a new science: Mary Anning and the fossil fish Squaloraja from the Lias of Lyme Regis. Proceedings of the Dorset Natural History and Archaeological Society, 108, $135-148$.

ThaCKRAY, J. C. 1976. James Parkinson's Organic Remains of a Former World (1804-1811). Journal of the Society for the Bibliography of Natural History, 7, 451-466.

TOPHAM, J. R. 1992. Science and popular education in the 1830s: The role of the Bridgewater Treatises. British Journal for the History of Science, 25, 397-430.

VINCENT, D. 1989. Literacy and Popular Culture: England 1750-1914. University of Cambridge, Cambridge.

WyATT, J. 1995. Wordsworth and the Geologists. Cambridge University, Cambridge. 